\title{
Internalizar a Voz do Cidadão e Transforma-la em Informação Estratégica na Gestão de Serviços de Saúde Hospitalar
}

\author{
Lemos, Claudia Regina Haponczuk de \\ Hospital das Clínicas da Faculdade de Medicina da Universidade de São Paulo - claudia.lemos@incor.usp.br
}

Introdução o sistema de ouvidoria na área da saúde no Brasil tem por alicerce os pilares do Sistema Único de Saúde, cujos princípios de Universalidade, Eqüidade e Integralidade e as diretrizes de Descentralização, Hierarquização, Regionalização e Participação Social são incorporados no direcionamento de suas ações. a consolidação da Ouvidoria de um Complexo Hospitalar Universitário, localizado na cidade de São Paulo/Br, foi definida em seu Regimento Interno (2006) levando-se em consideração: a responsabilidade social e ética da instituição; as diretrizes gerais para a administração; a visão de futuro e pensamento estratégico; a necessidade de aprendizado organizacional e, a importância da relação com os clientes. Objetivos Compartilhar um modelo de Ouvidoria considerado pioneiro em hospital público, que tem sua gênese em 1988, através da edição de uma Norma de Serviço instruindo que queixas por escrito fossem acolhidas pelo Serviço de Relações Públicas. em 1994 suas atribuições foram estabelecidas com a finalidade de assessorar o corpo diretivo na recepção, tramitação e encaminhamento das manifestações dos usuários. a Lei no. 10.294, de Defesa do Usuário do Serviço Público, de 1999, formalmente institui a figura do Ouvidor. Métodos o padrão de trabalho é estruturado e instrumentalizado por um sistema informatizado que classifica as manifestações em: Manifestante (acompanhante, funcionário, pacientes e outros);Provedor (Convênios, particulares e SUS);Canal de Comunicação (carta, e-mail, fax, telefone, site, pessoalmente e outros);Categoria (Competência de outro órgão, Infra-estrutura, Recursos Humanos, Procedimentos Operacionais e Legislação);Origem (Ambulatório, Internação e Emergência);Categoria (Denúncia, Elogio, Reclamações, Sugestão, Solicitação de Informações e Expressões Livres); Status (Em análise, Atendida, Não Atendida, Inconsistente e Encaminhada para outro órgão). É prerrogativa da Ouvidoria que todos os manifestantes recebam formalmente uma devolutiva. Resultados - São acolhidas anualmente em torno de 16.000 manifestações, sendo que aproximadamente $62 \%$ referem-se a queixas, $21 \%$ solicitação de informações, $13 \%$ elogios e $10 \%$ sugestões. o Ouvidor integra os Comitês Gestores dos institutos e os indicadores de Ouvidoria são apresentados e discutidos no Conselho Diretor da Superintendência, Produz Relatórios Gerenciais tanto para as lideranças locais como para gestores governamentais. Conclusões: a Ouvidoria municia a instituição com informações e avaliações procedentes diretamente de nossos clientes, traduzindo as necessidades e expectativas deste, com potencial para revisão e melhoria dos processos de atendimento da instituição e estabelecimento de políticas públicas de saúde. Zela pela imagem institucional na medida em que se constitui em canal de comunicação dos usuários com a Instituição, garantindo o direito do cidadão de participação e controle social.

Lemos, Claudia Regina Haponczuk de. Internalizar a Voz do Cidadão e Transforma-La em Informação Estratégica na Gestão de Serviços de Saúde Hospitalar.. In: Anais do Congresso Internacional de Humanidades \& Humanização em Saúde [= Blucher Medical Proceedings, num.2, vol.1]. São Paulo: Editora Blucher, 2014. ISSN 2357-7282 DOI 10.5151/medpro-cihhs-10690 